This item was submitted to Loughborough's Research Repository by the author.

Items in Figshare are protected by copyright, with all rights reserved, unless otherwise indicated.

\title{
Epilogue. Politeness research: sociolinguistics as applied pragmatics
}

PLEASE CITE THE PUBLISHED VERSION

http://dx.doi.org/10.1515/pr-2015-0014

\section{PUBLISHER}

(c) Walter de Gruyter GmbH

\section{VERSION}

VoR (Version of Record)

\section{PUBLISHER STATEMENT}

This work is made available according to the conditions of the Creative Commons Attribution-NonCommercialNoDerivatives 4.0 International (CC BY-NC-ND 4.0) licence. Full details of this licence are available at: https://creativecommons.org/licenses/by-nc-nd/4.0/

\section{LICENCE}

CC BY-NC-ND 4.0

\section{REPOSITORY RECORD}

Christie, Chris. 2019. "Epilogue. Politeness Research: Sociolinguistics as Applied Pragmatics”. figshare. https://hdl.handle.net/2134/18897. 


\section{Christine Christie}

\section{Epilogue. Politeness research: Sociolinguistics as applied pragmatics}

DOI $10.1515 / \mathrm{pr}-2015-0014$

\section{Introduction}

When I began to research for this epilogue to the tenth anniversary issue of the Journal of Politeness Research, my aim was to chart some of the key developments in the theorization of (im)politeness that had taken place over the past ten years in order to draw out the methodological impact of these re-theorizations. My initial research was guided by my hypothesis that, since (IM)POLITENESS $^{1}$ as a concept that has some currency within a given culture/cultural setting has been so radically rethought in the past ten years, there would be many examples of research questions that are being asked today that could not have been asked in the context of earlier theorizations. I had also assumed that these re-theorizations would have generated new methodologies. However when I returned to Brown and Levinson's (Brown and Levinson 1987 [1978]) theorization of politeness and to earlier examples of politeness scholarship, I was struck anew by some of the general principles underlying the theory and the extent to which, from the beginning, the theory has generated a wide range of sophisticated research questions. It was also clear that these questions had led to some carefully crafted analyses that were not slavishly designed to reinforce the claims of the theory. However they addressed questions which could not, without that theory, have been asked in the first place. An excellent example of such a study is Blum-Kulka's (1990) cross-cultural analysis of family discourse. I also became increasingly aware as I was looking for points of contrast that many of the research questions that I thought could only have been asked today could also have been generated by the original theory.

1 I use small capitals here to indicate that I am referring to the concept rather than the word politeness. That conceptualization might be realized as part of a theory or be a lay conceptualization.

Christine Christie, Loughborough University, E-mail: C.Christie@lboro.ac.uk 
I therefore modified the aims of this paper and, although I do chart developments in the field by pointing to new research questions and consider the methods that have been developed in order to address those questions, I do so in the context of a broader argument that emerged from my survey of developments in politeness research. My aim here is to argue that there is a key strength in the original theorization of politeness that it is important to retain as developments in the field continue: politeness research should balance the pragmatic with the sociolinguistic. I hope therefore that readers who are new to politeness research, as well as those who are familiar with scholarship in the field, will find it useful to reflect on the intellectual foundations of the approaches that are currently being developed on this tenth anniversary of the publication of the first issue of the Journal of Politeness Research so that the quality of future research can equal the quality of past research.

In what follows I consider Brown and Levinson's argument for an approach to politeness phenomena that engages with both sociolinguistics and pragmatics. They initiate this argument by articulating a goal that remains relevant for politeness research today: "The key problem in sociolinguistics is always the origin and nature of the social valence attached to a linguistic form" (Brown and Levinson 1987: 280). Their subsequent argument that "sociolinguistics should be applied pragmatics" (Brown and Levinson 1987: 281) arises from their proposal that a sociolinguistic investigation that addresses politeness behaviour from a pragmatic perspective is one way in which one aspect of that key problem can be addressed. In the next two sections I consider what it has meant in the past and what it means today for politeness research to constitute a sociolinguistic application of pragmatics.

In invoking Brown and Levinson's work, my argument here should not be read as a call to a return to the original theory since, as I show in what follows, the Brown and Levinson (1987 [1978]) theory is premised on a pragmatics and a sociolinguistics that is very different to the current manifestations of those fields. My point is that, as pragmatics and sociolinguistics evolve, politeness research should retain a balanced connection with the two fields. If we engage with the sociolinguistic without taking into account the pragmatic, and vice versa, we will lose one of the great sustaining strengths of politeness research. In order to argue this point, in section two below I summarize some key developments in sociolinguistics and in section three I summarize developments in pragmatics. In section four I consider the importance of politeness research that has both a pragmatic and a sociolinguistic basis. 


\section{The sociolinguistics of politeness research}

Brown and Levinson's proposition that sociolinguistics should be applied pragmatics means something quite different today compared to what it meant in 1978, when their theory was initially published, and in 1987 when their theory was republished with a section that addressed the critical responses that their original work had generated. Here I summarize some of the reasons that Brown and Levinson give for proposing that investigations into politeness phenomena should have a sociolinguistic dimension. I also consider some of the differences between the sociolinguistics Brown and Levinson are referring to and the scope of sociolinguistics today.

Given the date of the original theory, when they argue that sociolinguistics should be applied pragmatics, it is perhaps surprising that Brown and Levinson are not referring to (what has come to be known as) variationist sociolinguistics. They do say, in the context of a claim that politeness phenomena fall within the scope of pragmatics, that "the special interest of sociolinguistics in our view is in the differential use of such pragmatic resources by different categories of speakers in different situations" (Brown and Levinson 1987: 281). To this extent their conceptualization of social identity as existing separate from and prior to language-use is a product of its time. It is not distinct from that assumed by variationist sociolinguists in that it predates the constructivist conceptualizations of social identity that inform sociolinguistics today. However, this extended version of one of the above quotations indicates that they see the variationist model as offering too simplistic an account of how social meanings are assigned to linguistic resources:

The key problem in sociolinguistics is always the origin and nature of the social valence attached to linguistic form. Some sociolinguists view this as a relatively unmediated attribution of value on the basis of the social value of the group with which the linguistic forms are associated (Labov 1972c; Trudgill 1974a) (Brown and Levinson 1987: 280).

My point here is to show that it is on the basis of the premise that a given linguistic resource does not have a specific 'social valence'2 that can be derived from its association with a specific demographic grouping, that Brown and Levinson develop their argument that the 'attribution of value' requires a pragmatic analysis. As such, I'd argue that the specific sociolinguistics they are referring to is a form of interactional, qualitative sociolinguistics rather than a survey-

2 The meaning of the term valence here is not self-evident. I take it to mean 'power' or 'capacity' in that what it appears to refer to is the potential function of a linguistic resource. 
based quantitative sociolinguistics. And although its conceptualization of social identity and meaning generation are different to those of today's sociolinguistics, its goal is not inconsistent with the methodological drivers of third-wave sociolinguists today (see Eckert 2008, 2012) with their concern to investigate the dynamic nature of the social construction of meaning. And nor is it inconsistent with the focus on evaluative commentary in much recent politeness research.

Now, clearly, since Brown and Levinson's theory proposes that certain putative acts are inherently face-threatening, and since this premise has long been challenged, the research questions their theory generates are unlikely to be the same as those asked by current studies. Their position is evident in the statement that, for them, "communicative intentions have built-in social implications, often of a threatening sort" (Brown and Levinson 1987: 281). Moreover, their assumption that certain linguistic resources will generate politeness implicatures is predicated on a theory of communication that does not hold today. I will address this in more detail in the next section, but here, the point I want to make is that although most current politeness researchers would disagree with many of the premises underlying Brown and Levinson's version of politeness theory, the assumption that the goal of politeness research is to investigate the social values attributed to linguistic forms, and not to assume that they can be uncontroversially read off by the analyst, is as valid now as it was then. And I believe that this aspect of the framework should continue to guide politeness researchers.

The authors articulate the need to account explicitly for the meanings that are attributed to interactional phenomena in the following argument (which, interestingly, does not distinguish between the practices of anthropologists and sociolinguists):

Another point of immediate sociological relevance is methodological: anthropologists routinely make inferences about the nature of social relationships by observations of their interactional quality. They do this unreflectingly, on the basis of implicit assumptions about universal principles of face-to-face interaction. When made explicit these amount to principles like those here described. Until sociological methodology is explicit, descriptions will have an uncertain status and must be taken on the assumption that other observers so placed would similarly observe (Brown and Levinson 1987: 55 [emphasis mine]).

In the italicized elements of this quotation, Brown and Levinson are making the point that inferences about meaning carried out by scholars are not supported by evidence and argument because they are assumed to be uncontroversial and self-evident to all observers. They are also, of course, claiming that 
their own theory would allow these inferences to be appropriately supported. Whether it does or does not is not the issue here, however. My point is that if those italicized sentences were removed, the general principle that Brown and Levinson are arguing is one that still holds today, even though it is not always followed. My belief is that one reason why politeness research developed into an established field of inquiry is because the best examples have followed the principle that any sociolinguistic account of the meaning of interactional data has to be supported with an account that explains how such inferences are arrived at (whether or not the theory that accounts for those inferences is Brown and Levinson's).

Given this proposal that a strength of politeness research is the explanatory level that it adds to sociolinguistic data, what does it mean to investigate politeness as a pragmatic phenomenon that has a sociolinguistic dimension in 2015 ? To take just one development as an example, third wave variationist sociolinguistics is the product of a revision of the aims and methods of earlier forms of variation studies. The current concern is to investigate how the social meanings of linguistic resources are dynamically, and locally, generated (see in particular Eckert 2008 and 2012). A major premise of the current framework that Eckert (2008: 455) articulates is: "the meanings of variables are not precise or fixed but rather constitute a field of potential meanings". She glosses this field of potential meanings as "an indexical field, or constellation of ideologically related meanings, any one of which can be activated in the situated use of the variable". She argues that participation in discourse involves a continual interpretation of forms in context; an in-the-moment assigning of indexical values to linguistic forms. Her point is that whenever a linguistic resource is used, it has the potential to change its indexical field, and therefore the social meanings of linguistic resources are never entirely fixed. However, citing Silverstein (2003), she points out that meanings are 'always already immanent' because they take place within an ideological field, albeit one that is fluid and everchanging (Eckert 2008: 464).

To see politeness as having a sociolinguistic dimension in 2015 therefore is very different to that in 1978. It is premised on the assumption that the social meanings of linguistic resources are far more unstable than would have been envisaged at the time Brown and Levinson first developed their theory. Although it is assumed by the current framework that there are ideological constraints on the meaning potential of resources, and therefore that the meaning potential has a structured variation, third wave variationist sociolinguistics also theorizes the possibility of change through its focus on locally generated meanings that challenge the ideological constraints. The key goal of sociolinguistics that Brown and Levinson articulated remains a pertinent goal for current re- 
search, therefore: to account for the origin and nature of the social valence attached to linguistic form.

I would argue that politeness research is highly pertinent to this agenda as it is designed to provide a pragmatic account that can be used to investigate the meaning capacity of specific linguistic resources in specific contexts of use. It provides one way in which the field can build on and contribute to developments in sociolinguistics as well as strengthen the field of politeness research itself.

\section{The pragmatic element of politeness research}

Pragmatics in 1978 was also a very different field to that of 2015. As many critiques of Brown and Levinson's politeness theory have pointed out, in 1978, the dominant pragmatic framework was the Gricean model. I have argued elsewhere (Christie 2007) how the Gricean framework enabled and constrained the development of the original theory, so will rehearse this relationship very briefly here in order to show how a politeness theory today is embedded within quite a different pragmatics and therefore generates quite distinct research questions.

Although, between 1978 and 1987, the reliance of Brown and Levinson's theory of politeness on Gricean pragmatics had been heavily criticized, in the 1987 introduction to the theory the authors justify their retention of their original Gricean framework thus: "the only essential presumption is what is at the heart of Grice's proposals, namely that there is a working assumption by conversationalists of the rational and efficient nature of talk" (Brown and Levinson 1987: 4). Their point is that Grice's framework only informs their approach to politeness at a relatively abstract level and therefore the original does not warrant revision. The basic presumption that interlocutors assume that talk is rational and efficient, that Brown and Levinson take from Gricean theory, appears to be relatively uncontroversial and still holds for many pragmatic approaches today. However, the implications that the authors draw from this presumption (in the sentence following the above quotation) would only be generated by a normative framework such as Grice's:

It is against that assumption [i.e. of the rational and efficient nature of talk] that polite ways of talking show up as deviations, requiring rational explanation on the part of the recipient, who finds in considerations of politeness reasons for the speaker's apparent irrationality or inefficiency (Brown and Levinson 1987: 4). 
To be able to see the above statement as a corollary of the proposition that precedes it requires an additional premise: that the criterion against which talk is categorized as polite is a judgement about deviance. This in turn presupposes that there are norms of non-deviance against which an utterance can be judged. And, as many politeness theorists have since argued, these norms are now seen to be what Grice's maxims actually capture.

It is worth clarifying what is being stated here, as it will draw out some key differences between the Gricean model and the models that inform current pragmatics. According to the Gricean model, an utterance either is or is not deviant. If it is not deviant, the speaker is abiding by the maxims that instantiate the Co-operative Principle and is explicitly 'saying' what she 'means'. If the utterance is deviant, it is because the speaker is not following the maxims and therefore is not 'saying' what she 'means'. Since, according to the premises of the theory, the hearer expects that talk will be 'rational and efficient', the search for an implicature is triggered by this recognition that the utterance is deviant because it is 'indirect'. What Brown and Levinson add to this is that where that deviation is seen to be motivated by a concern for face, the result would be a politeness implicature.

There are a number of elements here that are untenable in the light of developments in pragmatics since 1978. Most significantly, as a recent Interpersonal Pragmatics special issue of the Journal of Pragmatics demonstrates, there is an increasing body of work that is predicated on the assumption that politeness evaluations are highly variable. As Haugh's paper in that issue (2013: 54) argues, current research in (im)politeness raises the question of: "just whose evaluations of im/politeness we are in fact analysing”. This assumption about the variability of interpretations of linguistic resources is now a given in pragmatics, and it derives from an acceptance of both the assumption that 'norms' are unstable and the assumption of linguistic undetermination can no longer questioned. Although there have been many developments in pragmatics, this single issue demonstrates that the pragmatics of today is not the pragmatics that informed Brown and Levinson's original theory, and shows why their theory is not workable today: if it is no longer assumed that a speaker can explicitly 'say' what she 'means', there can be no binary opposition between directness and indirectness that leads to a recognition of deviance, and therefore indirectness does not account for the generation of politeness implicatures.

However, as I argue in the previous section, even though the overall theory itself is no longer tenable, there are strong reasons for maintaining the link between the sociolinguistic and the pragmatic upon which Brown and Levinson's theory is predicated. The analytical framework that Brown and Levinson propose is a tool for describing "the quality of social relations" (Brown and 
Levinson 1987: 55). It is pragmatic (in the authors' own terms) because it involves an engagement with "the systematic relation of a language to context" Brown and Levinson 1987: 55). It is sociolinguistic because it asks questions about "the origin and nature of the social valence attached to a linguistic form" (Brown and Levinson 1987: 55). The theory aims therefore at offering both description (of patterns of behaviour) and explanation (what the function of that behaviour might be given the claims of their theory).

In the light of developments in the way that the pragmatics of social interaction is perceived, research questions that are asked in studies of (im)politeness increasingly relate to participants' evaluations of interactional behaviour and depend less on the analyst's application of a theoretical framework. There is a growing focus on metapragmatic comment as a source of understanding, both in the analysis of the interactional data, and in the analysis of post-interaction interview data. Such studies are designed to draw out the evaluations of participants as well as to assess the grounds for their evaluations. Mills, explains this development in this issue as follows:

Brown and Levinson take the (implicit) stance that it is unproblematic for analysts to evaluate the utterances of a speaker in a slightly decontextualized way, thus relying on the idea that utterances are inherently meaningful, and overlooking the hearer's understanding of the utterance. Instead, a discursive approach stresses the notion that meaning can be dynamically constructed by multiple participants over the course of longer stretches of discourse (Mills this issue: 182-183).

To this extent it is clear that in many ways the pragmatic underpinnings of current approaches to (im)politeness research are consistent with contemporary sociolinguistic concerns: the assumption that what counts as POLITENESS is not shared by all participants, but that politeness is a quality assigned to an utterance in the process of an interaction, fits well with the concerns of third wave sociolinguistics and with other contributions to this issue. They are evident in Kadar and Marquez-Reiter's (this issue) focus on the articulated legitimizations of speakers who intervene in perceived wrong-doings. And in Dynel's (this issue) mapping of impoliteness research, the problem of assessing evaluations is raised, with a particular focus on the problems of assessing evaluations of intention. This matter is also addressed in detail in Mitchell and Haugh's (this issue) analysis of construal of intention in their data. 


\section{Conclusion}

I argued above that Brown and Levinson's theory aims to be both pragmatic and sociolinguistic in that it offers both description (of patterns of behaviour) and explanation (what the function of that behaviour might be given the claims of their theory). Although that explanation is no longer provided by a wholesale application of their model, by proposing that the study of linguistic politeness is one way in which sociolinguistics can function as applied pragmatics, Brown and Levinson opened up a robust and extensive field of research. I would argue that one reason why politeness research has developed into such a strong field of inquiry is because, as the field has grown, the best examples of research have followed the principle that any sociolinguistic account of the meaning of interactional data has to be supported with an account that explains how such inferences are arrived at. However, in ending this epilogue, I would like to pose two questions: since, as I have shown here, the pragmatics and the sociolinguistics of 2015 have arrived at a point where both focus on the dynamic and local generation of meaning, has this led to an over-emphasis on what is dynamic and local about the process of meaning-making rather than on what is social and shared about the process? And does this matter?

\section{References}

Blum-Kulka, Shoshana. 1990. You don't touch lettuce with your fingers: Parental politeness in family discourse. Journal of Pragmatics 14. 259-288.

Brown, Penelope \& Stephen C. Levinson. 1987 [1978]. Politeness: Some universals in language usage. Cambridge: Cambridge University Press.

Christie, Christine. 2007. Relevance theory and politeness. Journal of Politeness Research 3. 263-288.

Eckert, Penelope. 2008. Variation and the indexical field. Journal of Sociolinguistics 12. 453-476.

Eckert, Penelope. 2012. Three waves of variation study: The emergency of meaning in the study of sociolinguistic variation. Annual Review of Anthropology 41. 87-100.

Haugh, Michael. 2013. Im/politeness, social practice and the participation order. Journal of Pragmatics 58. 52-57.

Labov, William. 1972. Sociolinguistic patterns. Philadelphia: University of Philadelphia Press. Silverstein, Michael. 2003. Indexical order and the dialectics of sociolinguistic life. Language and Communication 23. 193-229.

Trudgill, Peter. 1974. Sociolinguistics: An introduction. Harmondsworth: Penguin. 


\section{Bionote}

\section{Christine Christie}

Is a senior lecturer at Loughborough University. Her current research focuses on applications of relevance theory in the analysis of literature and of (im)politeness phenomena. Her published work falls primarily in the fields of language and gender studies, (im)politeness and pragmatics. 